\title{
PENGARUH MINAT DAN MOTIVASI BELAJAR TERHADAP PRESTASI BELAJAR MATEMATIKA
}

\author{
HERIYATI \\ erymatematika@gmail.com \\ Program Studi Teknik Informatika, Fakultas Teknik, Matematika dan IPA \\ Universitas Indraprasta PGRI
}

\begin{abstract}
Abstrak. Tujuan dari penelitian ini adalah untuk. Mengetahui pengaruh minat dan motivasi belajar terhadap prestasi belajar matematika siswa SMP Negeri di kecamatan Karawaci Tangerang. Sampel yang digunakan 63 siswa yang di peroleh dengan teknik random sampling. Pengumpulan data dengan kuesioner (angket) untuk mengukur minat dan motivasi belajar, sedangkan prestasi belajar matematika diambil dari nilai UAS. Hasil uji hipotesisnya, yaitu 1) Mengetahui pengaruh minat dan motivasi belajar secara bersama-sama terhadap prestasi belajar matematika siswa SMP Negeri di kecamatan Karawaci Tangerang. 2) Mengetahui pengaruh minat belajar terhadap prestasi belajar matematika siswa SMP Negeri di kecamatan Karawaci Tangerang. 3) Mengetahui pengaruh motivasi belajar terhadap prestasi belajar matematika siswa SMP Negeri di kecamatan Karawaci Tangerang.
\end{abstract}

Kata Kunci: Minat, Motivasi Belajar, Prestasi Belajar Matematika

\begin{abstract}
The purpose of this study is to. Knowing the influence of learning motivation and interest towards achievement of Junior High School students learn math in Karawaci subdistrict of Tangerang. The sample used in the 63 students who get with a random sampling technique. The collection of data by questionnaire (question form) to gauge interest and motivation to learn, while learning math achievement is taken from the value of the UAS. Test results whose hypotheses, namely 1) find out the influence of the interest and motivation of learning together towards the achievement of Junior High School students learn math in Karawaci subdistrict of Tangerang. 2) know how the learning interest towards achievement of Junior High School students learn math in Karawaci subdistrict of Tangerang. 3) know how the learning motivation toward achievement of Junior High School students learn math in Karawaci subdistrict of Tangerang.
\end{abstract}

Keywords: Interest In Learning Motivation, Achievement, Learning Math

\section{PENDAHULUAN}

Pendidikan mempunyai peranan yang sangat menentukan bagi perkembangan dan perwujudan diri individu terutama bagi pembangunan bangsa dan negara. Hal ini menjadi sangat penting dan perlu mendapatkan perhatian serius semua pihak terutama elemen yang terlibat dalam pendidikan dasar dan menengah sebagai cikal-bakal lahirnya manusia-manusia yang berkualitas. Pendidikan yang baik adalah pendidikan yang tidak hanya mampu melahirkan generasi intelektual, lebih dari itu produk pendidikan Indonesia harus bisa mengarahkan kader bangsa dalam mengasah kemampuan serta mengembangkan potensi yang dimilikinya secara optimal,menjadi orang yang berprestasi tinggi, memiliki etos kerja yang handal, kreatif inovatif dan tetap berbudi pekerti. Berbagai upaya telah dilakukan oleh para praktisi pendidikan khususnya di kota Tangerang untuk meningkatkan mutu pendidikan, dari mulai merubah dan merevisi kurikulum 94 menjadi kurikulum berbasis kompetensi (KBK) dan bahkan sekarang telah 
berganti menjadi Kurikulum Tingkat Satuan Pendidikan (KTSP) kemudian dilanjutkan dengan kurikulum 2013 hingga saat ini, peningkatan kompetensi guru, namun yang paling penting adalah bagaimana upaya-upaya tersebut bisa mencapai hasil yang maksimal sesuai seperti apa yang diharapkan.

Untuk mengembangkan potensi yang dimiliki siswa guru sebagai tenanga pendidik harus mengetahui faktor apa saja yang memengaruhi keberhasilan siswa dalam belajar dan mencapai prestasi. Ada dua faktor yang dapat memengaruhi keberhasilan siswa dalam belajar dan mencapai prestasi belajar yaitu faktor internal dan faktor eksternal. Faktor internal meliputi minat belajar, motivasi belajar, kecemasan belajar, kebiasaan belajar, tingkat kecerdasan dan kemampuan awal. sedangkan factor eksternal adalah lingkungan. Kendala lain yang juga berpengaruh adalah teknik mengajar atau metode pembelajaran yang dipergunakan oleh guru untuk mengajar atau menyajikan bahan pelajaran kepada siswa di dalam kelas maupun di luar kelas agar pelajaran tersebut tampak menarik serta lebih mudah dicerna, dipahami dan digunakan oleh siswa dengan baik.

Salah satu pelajaran yang kurang diminati siswa adalah matematika padahal matematika merupakan materi pelajaran yang mempunyaikarakteristik tersendiri sebagai ilmu pengetahuan dasar yang mesti diberikan kepada peserta didik untuk mengantar mereka ke pemikiran yang logis, rasional, kritis, cermat, jujur, efektif dan efisien.

Matematika bagi sebagian besar siswa masih dipandang sebagai pelajaran yang paling sulit dan mereka menganggapnya sebagai momok yang menakutkan. Hal ini bisa dilihat dari sikap keseharian siswa ketika pelajaran matematika berlangsung. Ada siswa yang merasa takut, cemas, pesimis, tidak berminat sehingga tidak termotivasi untuk menyelesaikan masalah matematika yang diberikan oleh guru. Sedangkan bagi siswa yang menyukai matematika dan memandang matematika sebagai mata pelajaran yang menantang dan menyenangkan, mereka akan merasa senang, semangat dan termotivasi untuk menyelesaikan masalah matematika yang diberikan oleh guru. Perbedaan pandangan dan sikap siswa terhadap matematika inilah yang dapat mempengaruhi prestasi belajar yang akan mereka capai.

Matematika sebagai ilmu memiliki objek kajian abstrak dan tersusun secara hirarkis. Seorang guru matematika harus berusaha mengurangi bahkan menghilangkan sifat abstrak dari objek kajian matematika itu untuk memudahkan siswa menangkap atau memahami pelajaran matematika di sekolah. Selain itu pada urutan hirarkis matematika menyebabkan setiap pemberian materi pembelajaran yang baru, siswa harus memahami bahkan mengingat materi sebelumnya. Karena alasan inilah banyak siswa merasa sulit menerima materi yang diajarkan oleh guru sehingga merekamerasa bahwa matematika itu merupakan pelajaran yang sulit, tidak menarik, dan membosankan. Anggapan inilah yang dapat melemahkan semangat belajar siswa sehingga berdampak kurangnya minat belajar siswa untuk mempelajari matematika dan kurangnya motivasi yang menyebabkan mereka menjadi acuh tak acuh ketika pelajaran matematika berlangsung.

Minat merupakan respon atas sesuatu yang disukai atau tidak disukai. Minat merupakan suatu aspek dari perilaku seseorang yang cenderung lebih kepada hal-hal yang positif, Pada kenyataannya banyak siswa yang tidak senang, merasa terpaksa atau sekedar melaksanakan suatu kewajiban. Minat siswa terhadap pelajaran merupakan kekuatan yang akan mendorong siswa untuk belajar. Siswa yang berminat sikapnya akan senang terhadap pelajaran danakan tampak terdorong terus untuk tekun belajar, berbeda dengan siswa yang sikapnya hanya menerima pelajaran yang guru berikan. Mereka hanya tergerak untuk mau belajar tetapi sulit untuk bisa terus tekun karena tidak ada pendorongnya. Minat juga sebagai salah satu faktor internal yang berperan dalam menunjang prestasi belajar siswa. siswa yang tidak berminat terhadap bahan pelajaran 
akan menunjukkan sikap yang kurang simpatik, malas dan tidak bergairah mengikuti proses belajar mengajar. Tentu hal tersebut merupakan akibat kurangnya pemahaman tentang hakikat, kemanfaatandan pengetahuan tentang matematika.

Selain minat, kerberhasilan siswa dalam belajar juga dipengaruhi oleh, faktor lain yang juga tidak kalah penting yaitu motivasibelajar.Motivasi sangat berperan penting dalam keberhasilan belajar siswa, karena motivasi merupakan dorongan yang timbul dari dalam diri siswa secara sadar atau tidak sadar yang bisa muncul dari dalam diri sendiri atau dari luar dirinya, untuk melakukan tindakan dengan tujuan yang dikehendaki. Namun pada intinya motivasi merupakan kondisi psikologis yang mendorong seseorang untuk melakukan sesuatu. Dalam kegiatan belajar, motivasi dapat dikatakan sebagai keseluruhan daya penggerak di dalam diri siswa yang menimbulkan, menjamin kelangsungan dan memberikan arah kegiatan belajar, sehingga diharapkan tujuan dapat tercapai. Siswa mempunyai minat belajar tinggi akan bersungguh-sungguh belajar karena termotivasi untuk mencapai prestasi

Dalam penelitian ini penulis memfokuskan hanya pada seberapa besar pengaruh minat terhadap prestasi belajar matematika, dan pengaruh minat belajar terhadap prestasi belajar matematika serta seberapa besar pengaruh minat dan motivasi belajar secara bersama-sama terhadap prestasi belajar matematika.

\section{TINJAUAN PUSTAKA}

\section{Prestasi Belajar Matematika}

Gagne dan Berliner dalam buku Educational Psycology yang dikutip oleh Dimiyati dan Mujiyono (2009:116) secara sederhana mengungkapkan bahwa "belajar adalah suatu proses yang membuat seseorang mengalami perubahan tingkah laku sebagai hasil dari pengalaman yang diperolehnya". Belajar juga merupakan proses yang melibatkan manusia secara orang perorang sebagai satu kesatuan organisme sehingga terjadi perubahan pada pengetahuan, keterampilan dan sikap.Hal ini sejalan dengan pendapat James O Whittaker dalam Abu Ahmadi dan Widodo, (2003:126) menyatakan bahwa “ Belajar dapat di definisikan sebagai proses dimana tingkah laku ditimbulkan atau dirubah melalui latihan atau proses pengalaman".

Seseorang yang telah mengalami proses belajar bisa dlihat dari adanya perubahan tingkah laku karena suatu pengalaman atau latihan yang berlangsung selama kurun waktu dan perubahan perilaku ini bersifat tetap atau konstan. Muhibbin Syah menyatakan bahwa belajar dapat dipahami sebagai tahapan perubahan seluruh tingkah laku individu yang relatif menetap sebagai hasil pengalaman dan interaksi dengan lingkungan yang melibatkan proses kognitif (Syah, 2001: 91).

Dapat disimpulkan bahwa belajar adalah pembentukan perubahan pada diri seseorang yang relatif tetap berupa aktifitas dan sikap yang melibatkan proses berpikir yang sangat kompleks. Proses belajar terbentuk didalam pikiran seseorang berdasarkan pemahaman dan pengetahuan-pengetahuan sebelumnnyayang diperoleh dengan cara mencoba, baik benar maupun salah sebagai suatu pengalaman dan berlangsung secara kontinu.

Prestasi belajar merupakan suatu ukuran (yaitu nilai numerik) atas jawaban seseorang atau pertanyaan -pertanyaan yang mencirikan karakteristik orang tersebut. Prestasi belajar adalah perubahan-perubahan dalam pengetahuan, pemahaman, keterampilan dan nilai sikap yang bersifat konstan atau menetap. Menurut Nasution, Prestasi belajar sebagai suatu perubahan yang terjadi pada individu yang belajar, bukan saja perubahan mengenai pengetahuan tetapi juga dalam bentuk kecakapan, kebiasaan, sikap, pengertian, penguasaan dan penghargaan dalam diri pribadi individu yang belajar.( Nasution, 2010: 22). 
Prestasi belajar yang dicapai seseorang merupakan hasil interaksi antar lingkungan, keluarga dan masyarakat sesuai pendapat Ahmadi (2003: 138) yang menyatakan bahwa “ prestasi belajar yang dicapai seseorang merupakan hasil interaksi berbagai faktor yang mempengaruhinya baik dari dalam diri (faktor internal) maupun dari luar diri (faktor eksternal) individu".

Prestasi belajar yang baik adalah keinginan yang dicita-citakan oleh setiap siswa maupun pendidik. Oleh karena itu yang merupakan tolok ukur keberhasilan proses belajar mengajar adalah prestasi belajar siswa. Apabila prestasi siswa baik, maka dapat dikatakan proses pengajaran oleh pendidik berhasil baik, tetapi jika prestasi belajar yang dicapai siswa rendah, maka dapat dikatakan bahwa pengajaran yang dilakukan oleh guru belum berhasil dengan baik.

Jadi prestasi belajar adalah tingkat keberhasilan siswa dalam pencapaian tujuan pembelajaran terhadap materi pelajaran berupa pengetahuan, keterampilan, serta nilai dan sikap, dapat dinyatakan dalam ukuran nilai yang merupakan prosentase pencapaian tujuan pembelajaran berkaitan dengan kemampuan para siswa dalam menguasai pelajaran

Tes prestasi belajar tidak lain adalah serangkaian pertanyaan yang harus dijawab atau tugas yang harus dikerjakan oleh siswa yang hasilnya dipakai untuk mengukur kemajuan belajar siswa sebagai bentuk perubahan-perubahan dalam pengetahuan, pemahaman, keterampilan dan nilai sikap siswa yang bersifat menetap. Ukuran kemajuan siswa dalam belajarnya dinyatakan dalam bentuk nilai yang merupakan prosentase pencapaian tujuan pembelajaran. Indikator-indikator yang menonjol yang mencerminkan bahwa terjadi proses belajar adalah adanya aktivitas dari pebelajar dan adanya perubahan sebagai hasil dari proses belajar. Aktivitas tersebut tidak terjadi dalam ruang hampa, melainkan dalam jaringan kontak-kontak yang bermakna dalam lingkungan yang berfungsi sebagai stimulan bagi subjek.

Menurut Nasution (2010:55) " matematika mempunyai urutan logis dan diajarkan menurut logika yang terkandung didalamnya.Hal ini sejalan dengan pendapat Soedjadi ( 2000:40 ) yang mengemukakan bahwa, " matematika merupakan ilmu pengetahuan mendasar yang harus diberikan kepada peserta didik untuk mengantar mereka ke pemikiran yang logis, rasional, kritis, cermat, jujur, efektif dan efisien". Jadi, matematika sangat diperlukan agar peserta didik dapat memiliki kemampuan memperoleh, mengolah dan memanfaatkan informasi untuk bertahan pada keadaan yang selalu berubah.

Dari teori dan penjelasan diatas maka Secara garis besar dapat disimpulkan bawa Prestasi belajar matematika adalah pencapaian tujuan pembelajaran baik dalam pengetahuan, pemahaman, keterampilan, dan nilai sikap siswa terhadap pelajaran matematika yang berupa nilai diperoleh dari ketekunan berlatih.

\section{Minat Belajar Matematika}

Minat adalah adalah ketertarikan seseorang akan sesuatu yang timbul dari dalam diri, Minat dapat mebangkitkan motivasi dan berprngaruh terhadap hasil dan prestasi belajar. Baharudin mengemukakan bahwa minat adalah kecenderungan dan kegairahan yang tinggi atau keinginan yang besar terhadap sesuatu (Baharudin 2008:24). Menurut Slameto minat pada dasarnya adalah penerimaan akan suatu hubungan antara diri sendiri dengan sesuatu diluar diri. Semakin kuat hubungan tersebut, semakin kuat minat. (Slameto, 2003: 57).

Dapat dijelaskan bahwa minat dapat membangkitkan motivasi pada diri seseorang. Timbulnya minat pada diri seseorang karena adanya ketertarikan dan perhatian pada satu obyek atau pelajaran tertentu disertai dengan perasaan senang, sehingga bila siswa tertarik pada sesuatu maka ia berusaha (termotivasi) untuk melakukan sesuatu yang diminatinya, sebaliknya tanpa minat seseorang tidak mungkin melakukan sesuatu. Minat 
juga dapat memengaruhi perhatian, belajar, berfikir dan pencapaian prestasi seseorang karena minat mengandung unsur-unsur perasaan agar seseorang merasa tertarik dan senang pada bidang tertentu.

Minat adalah sesuatu yang sangat penting dalam kegiatan belajar, karena dengan adanya minat dalam diri siswa akan membangkitkan atau mendorong siswa menjadi giat belajar dalam mencapai cita-cita yang ia inginkan.Jadi minat besar sekali pengaruhnya terhadap belajar, karena dengan minat siswa berusaha untuk mengetahui suatu pelajaran dengan cara mengetahui, mengikuti, dan memahami pelajaran. Setiap siswa mempunyai minat dan kebutuhan yang berbeda dengan siswa lain.

Minat dapat memengaruhi kualitas pencapaian hasil belajar siswa dalam bidang studi tertentu, umpamanya seorang siswa yang menaruh minat besar terhadap suatu mata pelajaran matematika, maka ia akan memusatkan perhatiannya lebih banyak daripada siswa lain. Kemudian, karena pemusatan perhatian yang intensif terhadap materi itulah yang memungkinkan siswa tadi untuk belajar lebih giat, dan akhirya mencapai prestasi yang diinginkan.

Minat belajar merupakan aspek psikologis yang memengaruhi hasil belajar. Adapun minat yang dapat menunjang belajar adalah minat kepada bahan atau mata pelajaran dan kepada guru yang mengajarnya. Peranan minat dalam belajar adalah sebagai kekuatan yang akan mendorong siswa untuk belajar. Siswa yang berminat pelajaran akan tampak terdorong terus untuk tekun belajar. menciptakan minat terlebih dahulu adalah cara yang sangat baik untuk memberikan motivasi pada diri untuk mencapai tujuan. Minat seseorang terhadap pelajaran dapat dilihat dari kecenderungan untuk memberikan perhatian yang lebih besar terhadap pelajaran tersebut.

Minat belajar matematika adalah minat siswa terhadap pelajaran matematika yang ditandai oleh perhatian siswa pada pelajaran matematika, kesukaaan siswa terhadap pelajaran matematika, keinginan siswa untuk tahu lebih banyak mengenai matematika, tugas-tugas yang diselesaikan oleh siswa, motivasi siswa mempelajari matematika, kebutuhan siswa terhadap pelajaran matematika dan ketekunan siswa dalam mempelajari matematika. Minat belajar matematika adalah perasaan senang terhadap pelajaran matematika dimana seorang siswa menaruh perhatian yang besar terhadap matematika dan menjadikan matematika pelajaran yang mudah.

\section{Motivasi Belajar}

Motivasi sebagai suatu keadaan atau kondisi yang timbul dari dalam diri seseorang. Motivasi ini memberikan pengaruh pada persepsi agar seseorang dapat melakukan kegiatan yang dapat dilihat dari perilaku yang di tunjukkan seseorang. Menurut Oemar Hamalik (2008:87), motivasi memiliki dua komponen yaitu komponen luar dan komponen dalam. Komponen luar adalah apa yang di inginkan seseorang, tujuanlah yang menjadi arah kelakuan nya. Sedangkan komponen dalam adalah perubahan di dalam diri seseorang, keadaan tidak puas, ketegangan psikologis.

Menurut Jex dalam izudin (2002: 210) motivasi seperti gravitasi yang tidak bisa dilihat secara visual atau dirasakan namun hanya bisa dilihat efek yang dihasilkan olehnya. Pada kehidupan sehari-hari motivasi memiliki peran yang sangat strategis termasuk pada proses pembelajaran. Bila seseorang merasa termotivasi oleh sesuatu hal maka ia akan mencoba sekuat tenaganya untuk mencapai tujuan tersebut sehingga pada akhirnya upaya tersebut akan diarahkan serta konsisten sesuai dengan tujuan. Motivasi merupakan suatu topik yang susah namun merupakan salah satu faktor terpenting untuk mencapai tujuan. Pada akhirnya, motivasi dapat didefinisikan sebagai suatu dorongan bersifatinternal, ataueksternal yang menjadi dasar dari setiap tindakan atau kegiatan yang dilakukan setiap orang untuk mencapai tujuannya. 
Motivasi belajar merupakan faktor yang mempunyai arti penting bagi seorang siswa. Apalah artinya siswa yang pergi kesekolah tanpa adanya motivasi belajar. Djamarah (2009:148). Dimiyati dan Mujiono menambahkan bahwa, "pada diri siwa terdapat kekuatan penggerak yang yang menjadi pemicu belajar yaitu motivasi belajar". (2009:80). Dalam kegiatan belajar, motivasi belajar merupakan keseluruhan daya penggerak di dalam diri siswa yang menimbulkan kegiatan belajar, menjamin kelangsungan dari kegiatan belajar dan yang memberikan arah pada kegiatan belajar sehingga tujuan yang dikehendaki oleh siswa dapat tercapai. Menurut Anurrahman Motivasi di dalam kegiatan belajar merupakan kekuatan yang menjadi tenaga pendorong bagi siswa untuk mendaya gunakan potensi yang ada dalam dirinya ( 2009:180 ).

Dari paparan di atas dapat dikatakan bahwa motivasi belajar adalah dorongan semangat belajar yang ditunjukkan dengan oleh siswa yang timbul pada diri seseorang secara sadar atau tidak. Dorongan itu muncul dari dalam dirinya atau luar dirinya dalam memperoleh berbagai pengetahuan, keterampilan, dan sikap dan diusahakan selalu berpartisipasi secara aktif, mempunyai minat, sikap dan persepsi tertentu, misalnya perasaan senang atau nyaman ketika berada didalam kelas.

Motivasi belajar matematika merupakan kecenderungan yang timbul pada diri seseorang secara sadar atau tidak sadar untuk memperoleh pengetahuan, pemahaman, keterampilan, dan nilai sikap siswa setelah mengikuti kegiatan belajar mengajar Matematika. Siswa yang mempunyai motivasi belajar yang tinggi akan berusaha meningkatkan pemahaman dan pengetahuannya tentang Matematika.

\section{METODE}

Metode dalam penelitian ini adalah survey dengan menggunakan tehnik analisis korelasional dan regresi ganda, yaitu mencari hubungan dan pengaruh antara dua variabel bebas dengan satu variabel terikat. Metode ini memberikan gambaran tentang variabelvariabel yang ditemukan, sekaligus menyelidiki hubungan dan pengaruh antara variabel, karena itu metode ini akan mengungkapkan data faktual berdasarkan informasi yang ditemukan. Penelitian ini dilaksanakan di SMP Negeri 20 Tangerang, pada bulan April sampai dengan bulan Juni 2015. Jumlah sampel dalam penelitian ini sebanyak 63 siswa yang dipilih dengan teknik random sampling.Dalam penelitian ini terdapat tiga variabel, yaitu dua varibel independen dan satu variabel dependent. Variabel independen yaitu: minat belajar $\left(\mathrm{X}_{1}\right)$, motivasi belajar $\left(\mathrm{X}_{2}\right)$. Yang dikumpulkan dengan menggunakan kuisioner atau angket. Sebelum kuisioner dijadikan alat pengumpul data, terlebih dahulu diadakan analisis instrumen yaitu uji validitas dan uji reliabilitas. Sedangkan variabel dependen yaitu Prestasi Matematika siswa (Y) di peroleh dari nilai UAS semester genap tahun ajaran 2014/2015 yang di peroleh dari dokumen sekolah.

Hubungan antar variabel dapat digambarkan dalam bentuk konstelasi masalah sebagai berikut:

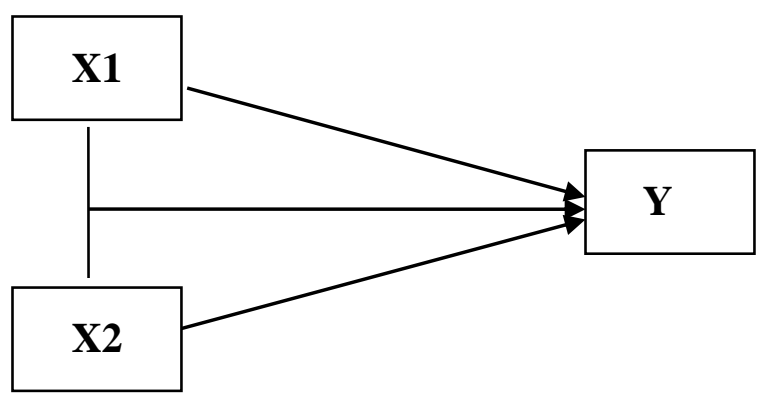

Gambar 1. Konstelasi Masalah Penelitian 
Keterangan:
$\mathrm{X}_{1} \quad$ : Minat belajar
$\mathrm{X}_{2} \quad$ : Motivasi belajar
Y : Prestasi belajar Matematika siswa

Dalam Pengujian hipotesis penelitian, perlu dilakukan analisa data. Tahapan analisis data meliputi: mendiskripsikan data untuk setiap variabel penelitian, melakukan uji persyaratan analisis, dan menguji hipotesis.

1. Hipotesis pertama yaitu Terdapat pengaruh yang signifikan minat dan motivasi belajar secara bersama-sama terhadap Prestasi belajar Matematika siswa, kedua Terdapat pengaruh yang signifikan motivasi belajar terhadap Prestasi belajar Matematika, diuji menggunakan korelasi dan regresi sederhana. Korelasi sederhana digunakan untuk mengetahui tingkat hubungan antara variabel bebas dan variabel terikat, sedangkan regresi sederhana digunakan jika variabel terikat (dependent variabel) tergantung pada satu variabel variabel bebas (independent variable).

2. Hipotesis ketiga Terdapat pengaruh yang signifikanmotivasi belajar terhadap Prestasi belajar Matematika diuji menggunankan korelasi dan regresi ganda. Korelasi ganda digunakan untuk mengetahui hubungan antara dua atau lebih variabel bebas dengan variabel terikat. Sedangkan regresi ganda digunakan jika suatu variabel terikat (dependent variabel) tergantung pada lebih dari satu variabel bebas (independent variable) atau Uji regresi dipakai untuk memprediksi pengaruh variabel bebas (independent variabel) terhadap variabel terikat (dependent variabel).

Adapun Persamaan regresi yang dikembangkan dalam penelitian ini adalah sebagai berikut:

Keterangan:

$$
\mathbf{Y}=\mathbf{a}+\boldsymbol{\beta}_{1} \mathbf{X}_{1}+\boldsymbol{\beta}_{2} \mathbf{X}_{2}
$$

$$
\begin{aligned}
& Y=\text { Prestasi belajar Matematika } \\
& X_{1}=\text { Minat belajar } \\
& X_{2}=\text { Motivasi belajar } \\
& a=\text { koefisien konstanta } \\
\beta 1, \beta 2= & \text { koefisien variable Independent }
\end{aligned}
$$

Penerapan model analisa regresi ganda adalah untuk mengukur intensitas pengaruh antara variable independent yang diteliti dari variabel minat belajar dan variabel motivasi belajar terhadap variabel dependent yaitu prestasi belajar matematika. Pengolahan data menggunakan program SPSS 20.

\section{HASIL DAN PEMBAHASAN}

Berdasarkan hasil pengolahan data diperoleh hasil sebagai berikut:

Tabel 1. Koefisien Determinasi

Summary Variabel $\mathrm{X}_{1}$ dan $\mathrm{X}_{2}$ terhadap $\mathrm{Y}$

Model Summary

\begin{tabular}{|r|r|r|r|r|}
\hline Model & R & R Square & \multicolumn{1}{|c|}{$\begin{array}{c}\text { Adjusted R } \\
\text { Square }\end{array}$} & $\begin{array}{c}\text { Std. Error of the } \\
\text { Estimate }\end{array}$ \\
\hline 1 & $.771^{\mathrm{a}}$ & .724 & .695 & 11.8 \\
\hline
\end{tabular}

a. Predictors: (Constant), Minat belajar, motivasi 
Untuk membuktikan ada atau tidaknya hubungan dan untuk mengetahui kekuatan antar variabel bebas $\mathrm{X}_{1}$ (Minat) dan $\mathrm{X}_{2}$ (Motivasi belajar) dengan variabel terikat (Prestasi belajar matematika) tersebut dilakukan dengan menggunakan analisi korelasi dari hasil perhitungan diperoleh koefesien korelasi berganda antara variabel $\mathrm{X}_{1}$ (Minat) dan $\mathrm{X}_{2}$ (Motivasi belajar) dengan variabel terikat (Prestasi belajar matematika) adalah dengan nilai $\mathrm{R}$ sebesar 0.771 maka menurut kriteria yang ada menunjukka bahwa hubungan kedua variabel cukup kuat. Sedangkan koefsien determinasi sebesar 0.724 menunjukkan bahwa besarnya konstribusi $\mathrm{X}_{1}$ (Minat) dan $\mathrm{X}_{2}$ (Motivasi belajat) dengan variabel terikat (Prestasi belajar matematika) adalah 72,4\% sisanya $27.6 \%$ karena pengaruh faktor lain.

Analisis korelasi ganda antara $\mathrm{X}_{1}$ dan $\mathrm{X}_{2}$ dengan $\mathrm{Y}$ menghasilkan koefesien korelasi ganda (Ry12) sebesar 0.771 Dari Koefeien Korelasi ganda diatas, diperoleh koefesien determinasi $\mathrm{R} 2=0,724$ atau $72,4 \%$, yang berarti terdapat pengaruh $\mathrm{X}_{1}$ (Minat) dan $\mathrm{X}_{2}$ (Motivasi belajar) secara bersama-sama terhadap variabel terikat (Prestasi belajar matematika). Hasil pengujian terhadap semua hipotesis yang diajukan dapat disimpulkan bahwa keseluruhan hipotesis penelitian yang dirumuskan dapat diterima. Dengan demikian berarti prestasi belajar matematika $72,4 \%$ dapat diperjelas oleh variabel minat dan motivasi belajar.

Tabel 2. Signifikansi Hubungan Minat dan Motivasi Belajar Terhadap Prestasi Belajar Matematika

Summary Variabel $\mathrm{X}_{1}$ dan $\mathrm{X}_{2}$ terhadap $\mathrm{Y}$

ANOVA $^{\mathrm{a}}$

\begin{tabular}{|c|c|c|c|c|c|c|}
\hline & & & & & & NOVA $^{a}$ \\
\hline & Model & Sum of Squares & $\mathrm{Df}$ & Mean & $\mathrm{F}$ & Sig. \\
\hline 1 & Regression & 8457.017 & 2 & 140.950 & 5.567 & $.000^{\mathrm{b}}$ \\
\hline & Residual & 50.634 & 60 & 25.317 & & \\
\hline & Total & 8507.651 & 62 & & & \\
\hline A. De & pendent varic & le: prestasi & & & & \\
\hline$P$ & lictors: (col & int), minat, mot & Belajar & & & \\
\hline
\end{tabular}

Tabel.3. Uji Signifikansi Koefisien regresi Ganda

Coefficients Koefesien Regresi Pengaruh Variabel $\mathrm{X}_{1}$ dan $\mathrm{X}_{2}$ terhadap $\mathrm{Y}$

\begin{tabular}{|c|c|c|c|c|c|c|}
\hline & \multirow[b]{2}{*}{ Model } & \multicolumn{2}{|c|}{ Unstandardized Coefficients } & $\begin{array}{l}\text { Standardized } \\
\text { Coefficients }\end{array}$ & \multirow[b]{2}{*}{$\mathrm{T}$} & \multirow[b]{2}{*}{ Sig. } \\
\hline & & B & Std. Error & Beta & & \\
\hline \multirow[t]{3}{*}{1} & (Constant) & -3.084 & 6.406 & & -.279 & .701 \\
\hline & Minat & .545 & .98 & 0.10 & 5.386 & .000 \\
\hline & $\begin{array}{l}\text { Motivasi } \\
\text { belajar }\end{array}$ & .809 & .149 & 0.78 & 7.696 & .000 \\
\hline
\end{tabular}




\section{Coefficients}

\begin{tabular}{|c|c|c|c|c|c|c|}
\hline & \multirow[b]{2}{*}{ Model } & \multicolumn{2}{|c|}{ Unstandardized Coefficients } & $\begin{array}{l}\text { Standardized } \\
\text { Coefficients }\end{array}$ & \multirow[b]{2}{*}{$\mathrm{T}$} & \multirow[b]{2}{*}{ Sig. } \\
\hline & & B & Std. Error & Beta & & \\
\hline \multirow[t]{3}{*}{1} & (Constant) & -3.084 & 6.406 & & -.279 & .701 \\
\hline & Minat & .545 & .98 & 0.10 & 5.386 & .000 \\
\hline & $\begin{array}{l}\text { Motivasi } \\
\text { belajar }\end{array}$ & .809 & .149 & 0.78 & 7.696 & .000 \\
\hline
\end{tabular}

a. Dependent Variable: Prestasi

belajar matematika

Uji keberartian korelasi ganda menghasilkan nilai F hitung sebesar 5.567 pada taraf sig 0.000 yang berarti signifikan. Dari daftar distribusi $\mathrm{F}$ dengan $\mathrm{dk}$ pembilang $1 \mathrm{dan} \mathrm{dk}$ penyebut $(n-3)=60$ pada taraf nyata $\alpha=0.05$ diperoleh $F$ tabel $=3.15$. Dengan demikian nilai Fhitung > Ftabel. Hal ini menunjukkan terdapat pengaruh $\mathrm{X}_{1}$ (Minat) dan $\mathrm{X}_{2}$ (Motivasi belajat) secara bersama-sama terhadap variabel terikat (Prestasi belajar matematika).

\section{Pembahasan}

Pengaruh Minat dan Motivasi belajar bersama-sama terhadap Prestasi belajar matematika

Berdasarkan perhitungan analisis diperoleh persamaan regresi $\mathrm{Y}=-3.084+0.545$ $\mathrm{X}_{1}+0.809 \mathrm{X}_{2}$. Nilai Konstanta $=3.084$ menunjukkan bahwa jika minat dan motivasi belajar buruk, maka tidak memungkinkan siswa disekolah tersebut mempunyai prestasi belajar yang baik, sedangkan nilai koefesien regresi sebesar $0.545 \mathrm{X}_{1}$ dan 0.809 menunjukkan bahwa terdapat pengaruh yang positif variabel $\mathrm{X}_{1}$ dan variabel $\mathrm{X}_{2}$ terhadap Y. Setelah dilakukan pengujian signifikan koefesien regresi dengan taraf nyata $\alpha=5 \%$ diperoleh $\mathrm{F}$ tabel 5.567 Dari daftar distribusi $\mathrm{F}$ dengan dk pembilang 1 dan dk penyebut $(\mathrm{n}-3)=60$ pada taraf nyata $\alpha=0.05$ diperoleh $\mathrm{F}$ tabel $=3.15$. Dengan demikian nilai Fhitung > Ftabel. Hal ini menunjukkan terdapat pengaruh $\mathrm{X}_{1}$ (minat) dan $\mathrm{X}_{2}$ (Motivasi belajar) secara bersama-sama terhadap variabel terikat (Prestasi belajar matematika).

Menurut Sintesis teori, Prestasi belajar merupakan suatu ukuran (yaitu nilai numerik) atas jawaban seseorang atau pertanyaan-pertanyaan yang mencirikan karakteristik orang tersebut. Prestasi belajar adalah perubahan-perubahan dalam pengetahuan, pemahaman, keterampilan dan nilai sikap yang bersifat menetap.

Dari pendapat diatas maka tes prestasi belajar tidak lain adalah pertanyaan yang harus dijawab atau tugas yang harus dikerjakan oleh siswa yang hasilnya dipakai untuk mengukur kemajuan belajar siswa sebagai bentuk perubahan-perubahan dalam pengetahuan, pemahaman, keterampilan dan nilai sikap siswa yang bersifat menetap. Ukuran kemajuan siswa dalam belajarnya dinyatakan dalam bentuk nilai yang merupakan prosentase pencapaian tujuan pembelajaran.

Indikator-indikator yang menonjol yang mencerminkan bahwa terjadi proses belajar adalah adanya aktivitas dari pebelajar dan adanya perubahan sebagai hasil dari proses belajar. Aktivitas tersebut tidak terjadi dalam ruang hampa, melainkan dalam jaringan kontak-kontak yang bermakna dalam lingkungan yang berfungsi sebagai stimulan bagi subjek. Demikian pula perubahan yang terjadi karena belajar merupakan perubahan yang positif dan relatif menetap. 
Belajar dipengaruhi oleh beberapa faktor diantaranya minat. Minat dapat memengaruhi perhatian, belajar, berfikir dan pencapaian prestasi seseorang karena minat mengandung unsur-unsur perasaan agar seseorang cenderung berbuat aktif dalam suatu pekerjaan, merasa tertarik dan senang pada bidang tertentu. Secara garis besar dapat di simpulkan bahwa minat adalah campuran antara perasaan, harapan, pendirian, prasangkan, rasa takut atau kecenderungan-kecenderungan lain yang bisa mempengaruhi perhatian dan cara berfikir seseorang kepada pilihan tertentu. Berdasarkan data pengolahan analisis kuantitatif dan teori tersebut peneliti berkesimpulan bahwa minat dan motivasi belajar mempunyai pengaruh yang positif dan signifikan secara bersama-sama terhadap prestasi belajar siswa.

\section{Pengaruh minat terhadap prestasi belajar matematika.}

Berdasarkan perhitungan analisis terdapat pengaruh yang positif variabel X1 dan terhadap Y. Hal ini dibuktikan dengan nilai $\mathrm{t}$ hitung $=5.386$ dan $\mathrm{sig}=0.000<0.05$. Menurut sintesis teori yang ada di bab II, Prestasi belajar merupakan suatu ukuran (yaitu nilai numerik) atas jawaban seseorang atau pertanyaan-pertanyaan yang mencirikan karakteristik orang tersebut. Prestasi belajar adalah perubahan-perubahan dalam pengetahuan, pemahaman, keterampilan dan nilai sikap yang bersifat konstan atau menetap. Dari dua pendapat diatas maka tes prestasi belajar tidak lain adalah serangkaian pertanyaan yang harus dijawab atau tugas yang harus dikerjakan oleh siswa yang hasilnya dipakai untuk mengukur kemajuan belajar siswa sebagai bentuk perubahan-perubahan dalam pengetahuan, pemahaman, keterampilan dan nilai sikap siswa yang bersifat menetap. Ukuran kemajuan siswa dalam belajarnya dinyatakan dalam bentuk nilai yang merupakan prosentase pencapaian tujuan pembelajaran. Berdasarkan data pengolahan analisis kuantitatif dan teori tersebut peneliti berkesimpulan bahwa minat mempunyai pengaruh yang positif dan signifikan terhadap prestasi belajar siswa.

\section{Pengaruh Motivasi belajar terhadap prestasi belajar matematika.}

Berdasarkan perhitungan analisis terdapat pengaruh yang positif variabel X1 dan terhadap Y. Hal ini dibuktikan dengan nilai t hitung= 7.696 dan sig $=0.000<0.05$. Menurut sintesis teori, Prestasi belajar merupakan suatu ukuran (yaitu nilai numerik) atas jawaban seseorang atau pertanyaan-pertanyaan yang mencirikan karakteristik orang tersebut. Prestasi belajar adalah perubahan-perubahan dalam pengetahuan, pemahaman, keterampilan dan nilai sikap yang bersifat konstan atau menetap. Dari pendapat diatas maka tes prestasi belajar tidak lain adalah serangkaian pertanyaan yang harus dijawab atau tugas yang harus dikerjakan oleh siswa yang hasilnya dipakai untuk mengukur kemajuan belajar siswa sebagai bentuk perubahan-perubahan dalam pengetahuan, pemahaman, keterampilan dan nilai sikap siswa yang bersifat menetap. Ukuran kemajuan siswa dalam belajarnya dinyatakan dalam bentuk nilai yang merupakan prosentase pencapaian tujuan pembelajaran. Indikator-indikator yang menonjol yang mencerminkan bahwa terjadi proses belajar adalah adanya aktivitas dari pebelajar dan adanya perubahan sebagai hasil dari proses belajar. Aktivitas tersebut tidak terjadi dalam ruang hampa, melainkan dalam jaringan kontak-kontak yang bermakna dalam lingkungan yang berfungsi sebagai stimulan bagi subjek. Demikian pula perubahan yang terjadi karena belajar merupakan perubahan yang positif dan relatif menetap.Menambah adanya faktor pendukung motivasi, yakni setiap tindakan yang dilakukan oleh setiap orang selalu akan digerakkan oleh faktor-faktor tertentu dari dalam hatinya untuk mencapai suatu tujuan. Faktor penggerak ini disebut motif. Motif adalah suatu kebutuhan, keinginan, dorongan atau impuls-impuls yang muncul dalam diri seorang individu. Berdasarkan data 
pengolahan analisis kuantitatif dan teori tersebut peneliti berkesimpulan bahwa motivasi belajar mempunyai pengaruh yang positif dan signifikan terhadap prestasi belajar siswa.

\section{PENUTUP}

Penelitian bertujuan untuk mengetahui pengaruh minat dan motivasi belajar, secara sendiri-sendiri maupun secara bersama-sama, terhadap prestasi belajar matematika siswa SMP Negeri di Kecamatan Karawaci Tangerang diperoleh kesimpulan sebagai berikut:

1. Terdapat pengaruh yang signifikan minat dan motivasi belajar secara bersama-sama terhadap prestasi belajar matematika. Hal ini dapat dibuktikan dengan nilai $\mathrm{F}$ hitung $\left(\mathrm{F}_{0}\right)=5.567>\mathrm{F}$ tabel $=3.15$ dan Sig. $=0,000<0,05$

2. Terdapat pengaruh yang signifikan minat belajar terhadap prestasi belajar matematika. $\mathrm{Hal}$ ini dapat dibuktikan dengan $\mathrm{t}$ hitung $\left(\mathrm{t}_{0}\right)=5.386>\mathrm{t}$ tabel $=1.67$ dan Sig. $=0,000$ $<0,05$.

3. Terdapat pengaruh yang signifikan motivasi belajar terhadap prestasi belajar matematika siswa. Hal ini dapat dibuktikan dengan $\mathrm{t}$ hitung $\left(\mathrm{t}_{0}\right)=5.386>\mathrm{t}$ tabel $=$ 1.67 dan Sig. $=7.696<0,05$.

\section{DAFTAR PUSTAKA}

Ahmadi, Abu, 2003, Teknik Belajar yang Tepat, Mutiara Permata Widya, Semarang

Ahmadi, Abu dan Widodo S. 2003. Psikologi Belajar. Jakarta: Rineka Cipta

Aunurrahman. 2009. Belajar Dan Pembelajaran. Bandung: Alfabeta

Baharuddin, 2008. Teori Belajar dan Pembelajaran Jogjakarta: Ar Ruzz Media.

Dimyati dan Mudjiono. 2009. Belajar dan Pembelajaran. Jakarta: Rineka Cipta.

Djamarah, Syaiful Bahri. 2006. Psikologi Belajar. Jakarta: Rineka Cipta

Hamalik, Oemar. 2008. Kurikulum dan Pembelajaran. Jakarta: Sinar Grafika.

I.A, Suparman. 2013. Aplikasi Komputer dalam Penyusunan Karya Ilmiah.

Tangerang: PT. Pustaka Mandiri

Nasution.A.H.1992. Landasan Matematika Jakarta: Bharata Karya Aksara.

Nasution S. 2010. Teknologi pendidikan Jakarta: Bumi Aksara.

Slameto. 2003. Belajar dan Faktor- Faktor yang Mempengaruhinya. Jakarta: Rineka Cipta.

Syah, Muhibbin. 2001. Psikologi Pendidikan dengan Pendekatan Baru. Bandung: Remaja Rosdakarya.

Roida E.F.S. 2012 Pengaruh minat dan kebiasaan terhadap prestasi belajar.Jurnal Formatif 2 (2): 122-131 ISSN: 2088-351X.

Izuddin Syarif 2012. Pengaruh model blended learning terhadap motivasi dan prestasi belajar siswa smk. Jurnal Pendidikan Vokasi, Vol 2, Nomor 2, Juni 2012 uny 20882866. 